\title{
Tradition and Technology with special respect to Dhouta Samskara of Shatadhouta Ghrita
}

\author{
Research Article
}

\section{Sreevathsa $S^{1 *}$, Bharathi B Hiremath ${ }^{2}$, Dileep Kumar ${ }^{2}$, Shivappa Pujari², Rajesh $\mathbf{V M}^{3}$}

\author{
1. Professor (I/C) \& HOD, 2. PG Scholar, \\ 2. Department of PG Studies in Ayurveda Siddhantha, \\ Government Ayurveda Medical College, Mysore, Karnataka \\ 3. JSS Pharmacy College, Mysore, Karnataka
}

\begin{abstract}
Ayurveda the science of health care system of medicine has been considered very important since ages. It has narrated many important principles regarding svastya (health), ahara (diet), vyadhi (disease) and aoushadha kalpanas (formlation of medicine). Ghrita is one among the chaturvidha sneha explained in Ayurveda and widely used as ahara and aoushada. Many ghrita samskara's are explained in classical texts of Aurveda. Shatadhouta ghrita is one such unique preparation and an example for dhouta samskara. And in laboratory it is evaluated for its $\mathrm{pH}$, organoleptic, properties, moisture content, molecular size, viscosity, copper content, acid value, saponification value, iodine value in JSS Pharmacy College Mysore. Hence an attempt is being made to prepare and analyze the Shatadhouta ghrita in laboratory and to emphasize the importance of samskara explained in Ayurveda.
\end{abstract}

Keywords: Shatadhauta Ghruta, Organoleptic properties, Sneha

\section{Introduction}

Ayurvedic system of medicine, evolved over the ages, had been completely looking after the healthcare of the world. As contemporary system of medicine used knowledge of modern biology and chemistry, for both discovery and treatment, it found fast acceptability. In spite of this, the contribution of the Ayurvedic system of medicine to healthcare is enormous. Acharya Caraka clearly states the indications for ghee. Ghee "promotes medha, (intelligence), smriti (memory)

\section{*Corresponding Author:}

\section{Sreevathsa}

Professor \& HOD,

Department of PG Studies in Ayurveda

Siddhantha,

Govt. Ayurvedic Medical College,

Mysore. Karnataka

E-mail: dr.shreevathsa@ rediffmail.com agni (factor responsible for digestion, metabolism, and biotransformation), sukra, ojas, kapha and medas. It alleviates vata, pitta, visha, unmada, apasmara, ashubha and jwara. It is the best among chaturvidha sneha. It is of sheeta veerya, madhura rasa, madhura vipaka, has thousand potentialities and so, if used properly according to prescribed methods, exerts thousand types of actions.(1) In the study, the Ayurvedic preparation Shatadhouta ghrita has been evaluated for its physicochemical parameters and changes occurring during washing were analyzed. An attempt has made to find out answer to samskara and prabhava through modern technology. An attempt is made to prepare manually and find out the rationale behind washing cow's ghee hundred times with water. Evaluated for its $\mathrm{pH}$, organoleptic properties, Moisture content, Molecular size, Viscocity, Copper content, Acid 
value, Saponification value and Iodine value. It was found that Shatadhouta ghrita exhibits a much less degree of unsaturation (suggesting better physico-chemical stability) and better consistency and hence suitability for topical applications. The aim of present study investigation is to prepare and evaluate Shatadhouta ghrita in terms of samskara and tecnology.

\section{Review of literature;}

Acharya Susruta in uttaratantra mentioned shatadhouta ghrita in jwara for daha shamana. The procedure told as to wash ghee for hundred times in cold water. The resultant ghee is known as Shatadhouta ghrita and it is of light in consistency. (2)

If there is bleeding during fourth month of pregnancy then below the naval region, the entire body of the pregnant woman should be smeared with Shatadhouta ghrita or sahsra dhouta ghrita.

In kusta chikitsa Acharya Charaka says that if there is daha in kusta, then for dahashamanartha (for pacification of burning sensation) abhyanga (massage with ghee) is adviced with tiktaghrita or Shatadhouta ghrita. (3)

This is an effective remedy for visarpa (herpis) ,when applied repeatedly by mixing equal quantity of fine powder of Pancha Valkala, it subsides daha (burning sensation), shoola (pain) in vrana (wound) and cures visarpa like that of garuda killing the sarpa (4)

Shatadhouta ghrita used as pralepa in the technique of scraping of eye lids and other disorder of the eye lids. (5)

In Sushruta kalpa sthana shatadhouta ghrita is indicated in visha chikitsa. A poultice prepared from the anti-venomous drugs of cooling potency mixed with Shatadhouta ghrita and applied over the kothayukta vrana (gangrenous wound). (6)

In pregnant woman, with unexplained bleeding or spotting, traditionally, it is advised to apply this shatadhouta ghrita around umbilicus. (7)
Objectives;

○ To compile the literature of Shatadhauta Ghruta.

- To prepare, analyze the prepared shatadhauta Ghruta with the help of laboratory techniques.

- To find an answer to dhouta samskara in terms of modern technology.

- To compare properties of Ghrita and Shata dhouta ghrita.

\section{Materials and Methods;}

Shatadhauta Ghruta was prepared by the scholar as per the classical method and analysis was done at JSS Pharmacy College, Mysore.

\section{Ingredients in the preparation of Shatadhouta ghrita}

- Nandini Company Cow's ghee 200gms

- Normal Tap Water

- Plate made out of Copper

\section{Procedure:}

Nandini company Cow's ghee of $200 \mathrm{gm}$ is taken in a copper plate. Normal tap cold water is added above the level ofghee. Ghee and water rubbed vigorously for 6-8minutes till water become slightly warm, and the contents were allowed to settle. Water was decanted carefully, avoiding loss of ghee. Then same cold tap water was added to the previously washed ghee and similar procedure was repeated. This operation was carried out for one hundred times to obtain Shata dhouta ghrita. Samples were collected after washing and stored in plastic container at room temperature for analysis. Normal Nandini company Cow's ghee of $200 \mathrm{gm}$ is anlysed in laboratory along with the analysis of shatadhouta ghrita.

\section{Methodology}

1. Organoleptic Tests

2. Laboratory Tests; Acid value, ester value, saponification value, iodine value, 
peroxide value of shatadhouta ghrita were determined by the methods outlined in pharmacopoeias.(9) All the chemicals are provided from the JSS Pharmacy college Mysore.All the solvents are distilled before use. Nandini cow ghee is purchased from Nandini milk dairy Mysore. Cow ghee was observed for its organoleptic properties and analyzed for various physicochemical parameters (moisture content, viscosity, acidvalue, saponificationvalue, iodinevalue, etc) prescribed for lipids in Pharmacopoeas (IP,USP).Particle size was also determined.(The united State Pharmacopoeia 27, The national Formulary22,United states Pharmacopoeial Convention ,INC,Asian Edition 2004,2389-2401)

\section{Results;}

Organoleptic Properties

\begin{tabular}{|l|l|l|}
\hline $\begin{array}{c}\text { Organo- } \\
\text { leptic } \\
\text { properties } \\
\text { Parameter }\end{array}$ & $\begin{array}{c}\text { Nadini Cow's } \\
\text { Ghee }\end{array}$ & $\begin{array}{l}\text { Shatadho } \\
\text { uta ghrita } \\
\text { prepared } \\
\text { in } \\
\text { Tamrapat } \\
\text { ra }\end{array}$ \\
\hline Colour & $\begin{array}{l}\text { Golden yellow } \\
\text { colour }\end{array}$ & White \\
\hline Odour & $\begin{array}{l}\text { Typical ghee } \\
\text { smell }\end{array}$ & Odourless \\
\hline Taste & Charecteristic & Tasteless \\
\hline Texture & Grannular,oily & $\begin{array}{l}\text { Smooth, } \\
\text { oily, } \\
\text { homogeno } \\
\text { us mass }\end{array}$ \\
\hline Weight & $200 \mathrm{gm}$ & $\begin{array}{l}\text { Increased } \\
\text { after wash } \\
\text { from } \\
\text { 200gm } \\
\text { to250gm }\end{array}$ \\
\hline
\end{tabular}

\section{Chemical Properties}

\begin{tabular}{|c|c|c|}
\hline $\begin{array}{c}\text { Chemical } \\
\text { properties } \\
\text { Parameter }\end{array}$ & $\begin{array}{c}\text { Nandini } \\
\text { Ghee }\end{array}$ & $\begin{array}{c}\text { Shatadhout } \\
\text { a ghrita } \\
\text { prepared in } \\
\text { tamrapatra }\end{array}$ \\
\hline Acid value & $1.79 \pm 0.01$ & $\begin{array}{c}0.097 \\
\text { (decreased) }\end{array}$ \\
\hline
\end{tabular}

\begin{tabular}{|c|c|c|}
\hline $\begin{array}{c}\text { Saponificatio } \\
\text { n value }\end{array}$ & $\begin{array}{c}249.4 \pm 0.3 \\
2\end{array}$ & $\begin{array}{c}9.987 \\
\text { (decreased) }\end{array}$ \\
\hline Iodinevalue & $\begin{array}{c}35.49 \pm 0.3 \\
5\end{array}$ & $\begin{array}{c}31.14 \\
\text { (decreased) }\end{array}$ \\
\hline
\end{tabular}

\section{Physical properties}

\begin{tabular}{|l|c|c|}
\hline \multicolumn{1}{|c|}{$\begin{array}{c}\text { Physcical } \\
\text { parameters }\end{array}$} & $\begin{array}{c}\text { Nandini } \\
\text { Ghee }\end{array}$ & $\begin{array}{c}\text { Shatadho } \\
\text { uta ghrita } \\
\text { prepared } \\
\text { in } \\
\text { tamrapat } \\
\text { ra }\end{array}$ \\
\hline Moisture content & 0.27 & $\begin{array}{c}0.8 \\
\text { (increase } \\
\text { d) }\end{array}$ \\
\hline Ph & 4.6 & $\begin{array}{c}5.4 \\
\text { (increase } \\
\text { d) }\end{array}$ \\
\hline Particle size & 179.02 & $\begin{array}{c}51.56 u m \\
\text { (decrease } \\
\text { d) }\end{array}$ \\
\hline $\begin{array}{l}\text { Viscosity (cp) at } \\
\text { 20rpm for 30 } \\
\text { seconds }\end{array}$ & 8000 & $\begin{array}{c}9650 \\
\text { (increase } \\
\text { Copper } \\
\text { content(ppm) }\end{array}$ \\
\hline
\end{tabular}

\section{DISSCUSSION}

Preparation of Shatadhouta ghrita can be illustrated as follows. Initially, the pure lipid phase, i.e. ghee comes in contact with an aqueous phase. Due to rubbing, it results in formation of water in oil type of emulsion as lipid phase (Cow Ghee) is a major phase. As the washing continuous, due to pressure applied during rubbing, particle size of fat granules gets reduced. Eventually, successive washings result in oil in water type of emulsion. It is possible that it might lead to formation of a complex system like water oil water emulsion. The characteristic granular, oily consistency and odor present in the ghee is lost, resulting in a homogeneous, smooth, nonoily product, which is easier to apply, thus improving the patient compliance as a base for topical application. $\mathrm{pH}$ change from acidic to neutral makes it beneficial to 
prevent skin irritation. Hence, the preparation may be applied on open wounds. When comparision is made between Ghrita and Shatadhouta ghrita the properties of Ghrita differs from Shatadhouta ghrita.

Reduction in particle size of Shatadhouta ghrita makes the product nongranular, non-sticky, homogeneous, with a large surface area, similar to that of modern cream base which makes it easy to apply on skin and may result in increased rate of absorption through skin. Viscosity of Shatadhouta ghrita was found to have increased in the conversion from ghee to Shatadhouta ghrita, washing results in the formation of a homogenous mass of oil in water emulsion with better consistency and viscosity which helps in its topical application and is beneficial in removal of scars and as anti-inflammatory activity. Because of its lower iodine value of Shatadhouta ghrita indicates the decrease in degree of unsaturation, which eventually reduces the chances of rancidity, thus increase stability of the product. Decrease in acid value with repeated washings indicates the reduction in free fatty acids.

The findings are consistent with the following mechanism of formation of Shatadhouta ghrita which is also supported in literature. (10) Fat splitting is a process in which, fat is hydrolyzed in the presence of water to yield free fatty acids and glycerols. High temperature and pressure are known to accelerate the process of hydrolysis. In the preparation of Shatadhouta ghrita although temperature is kept constant, there is repeated and prolonged washing of the ghee and fat mixture. Thus the pressure factor may contribute to fat splitting. After each washing, aqueous phase is withdrawn and replaced by fresh slot of the same. If the reactants and products are not removed from the sphere of the reaction, equilibrium will eventually be reached, depending upon the concentrations of the former. In practice, by using a large excess of water and repeatedly withdrawing the glycerol rich aqueous phase and replacing it with fresh water, the process of fat splitting is accelerated. Decrease in the degree of unsaturation can be supported by the absence of unsaturated fatty acids such as oleic acid, palmitic acid and lauric acid in Shatadhouta ghrita. (11-12)

Above mentioned analysis can be supported with the textual informations given in Charaka Samhita and thus brief note on that has given below. Sarpi, Taila, Vasa, Majja. Ghrita (ghee), taila (oil), vasa (fat), majja (bonemarrow)-these are regarded as the best sneha dravyas (oil substaces).Among all the sneha dravyas Ghrita (ghee) is the best one because of the continuance of the properties of refinement (13)

Nirvapana means that which pacifies burning sensation. Sthirakara is that which provides stability to organs. Acharya Gangadhar explained Nirvapana by saying that it is pacifying heat and burning as if from fire. Mridukara is that which produces softness. (14)

Processing is the making or refinement of the natural products which means imparting other properties. These properties are infused by contact of water and fire, Cleansing, churning, place, time, infusing, steeping and also by long duration, utensil etc. (15)

Ghee alleviates pitta and vata it is beneficial for rasa, sukra and ojas, cooling, softening and improves voice and complexion. (16)

\section{Conclusion}

From the present work, it can be concluded that changes taking place in cow ghee while washing it with hundred times to prepare Shatadhouta ghrita, makes it an elegant and suitable product for topical application. Ghrita and shatadhouta ghrita differ in their properties. Basic quality of ghee is cooling and softening along with it, it is best in samskaranuvartana. With its cooling quality it acquire the cooling effect 
of jala and vrana ropana property by samskaras followed during the preparation like cleansing, churning, time and utensil. Increase in moisture content useful for skin hydration and cooling effect, which can justify its use for the treatment of burns $\mathrm{pH}$ change from acidic to neutral, makes it beneficial to prevent skin irritation, significant in removal of scars and as an anti-inflammatory agent. Chemical analysis and Samsakara siddhanta of Ayurveda prove Shatadhouta ghrita is effective and act as good cooling agent, emollient, moisturizer and good scar healer. Samskara of Ayurveda is explained through modern lab techniques.

\section{Reference}

1. Cakrapani's Ayurveda Dipika, 1st ed., Indian Medical Science series, Sri Satguru Publications: Delhi (1999).

2. Susruta samhita of susruta part 2 by GD Singhal chowkamba Sanskrit publication second edition 2007

3. Charakasamhita text with egnlish translation on chakrapani dattas ayurveda dipika vol2 by Rk Sharma Bhagavandash 2009

4. Yogaratnakara PT Sadashiva Shashtri joshi published by Jayakrisna das haridas gupta chowkamba Sanskrit series banaras 1939

5. Susruta samhita of susruta by part3 GD Singhal chowkamba Sanskrit publication second edition 2007

6. Susruta samhita of susruta by part3 GD Singhal chowkamba Sanskrit publication second edition 2007

7. Astanga hridaya vidyotini bhasha tika kaviraj atridev gupta 4th edition chowkamba Sanskrit series banaras 1939
8. Anonymous.

The

Indian Pharmacopoeia.Vol. 2, Part 1. New Delhi: Govt. Of India publication: A50 (1996).

9. Agraval OP, Chemistry of Organic Natural Products, Vol. II, Goel Publishing House, Meerut: 429-455 (1994).

10. James CS, Analytical Chemistry, Aspen Publication, Malaysia: 140-143, (1999)

11. 0975-6299As per pharmacopoeial standards Ravindra r.p.* and pata muslim k. Department of pharmaceutics, svkm's nmims, school of pharmacy \& Technology management, shirpur, dist. Dhule, maharashtra, india- 425405.

12. Supriya D, Avinash D, Suresh T, Anoop A, Shata -Dhauta -Ghrita -A Case Study. Indian Journal of Traditional Knowledge. 8(3): 387-391, (2009).

13. Charaka samhita vol 1 text with English translation by P.V.Sharma chaukambha orientalia Varanasi edition 7 2001)

14. Ch su $13 / 17$ charaka samhita vol 3 text with English translation by P.V. Sharma chaukambha orientalia Varanasi reprint ninth edition 2007

15. Charaka samhita vol 1 text with English translation by P.V.Sharma chaukambha orientalia Varanasi edition 72001

16. Charaka samhita vol 1 text English translation by P.V. Sharma chaukambha orientalia Varanasi edition 7 2001) with 